WŁADYSŁAW ŁYDKA

Studia Theologica Varsaviensia

UKSW

2020

\title{
The Need and Ways of Integration in Christology*
}

\section{Introduction}

The last Council calls for a renewal of seminary studies to be aimed at opening up the minds of the Alumni increasingly more "to the mystery of Christ, which permeates the entire history of the human race, has a constant influence on the Church and acts mainly through the priestly ministry." It encourages that in addition to dogmatics other theological teachings should strive for renewal through a more lively connection with the mystery of Christ and the history of salvation. He demands that the lectures of dogmatics be coordinated with other theological sciences taking into account the biblical themes, the teachings of the Eastern and Western Fathers, the history of dogmas, as well as exploring the mysteries of 'begetting and discovering the connection between them. Alumni are to learn to perceive the presence of these mysteries in the liturgy and in the whole life of the Church, to solve human problems in the light of revelation, to apply God's eternal truths to the changing conditions of human life and to proclaim these truths in a way that is accessible to all people ${ }^{2}$.

The Council itself did not draw up any special constitution on Christ but in many of its documents it put Christ at the centre of the whole history of salvation and stressed the connection of Christology to other branches of theology: the science of the Trinity, ecclesiology, the sacrament of anthology, anthropology, protology of eschatology.

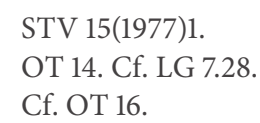




\section{The necessity of Christological Correlation in Theology}

From the postulates of the Council there is an unambiguous need for inter-departmental cooperation in the field of Christology, the need for dogmatics to take into account the achievements and demands of other theological disciplines and some Christocentric orientation of these disciplines, and thus to constantly refer to the Christological synthesis to be created by renewed dogmatics ${ }^{3}$. The need for a Christological correlation of theology stems from the essential unity of its subject, origin and purpose. Despite its fragmentation into many disciplines and treaties, theology is in its essence a scientific, methodical reflection on different aspects of one and the same mystery of salvation, fully revealed and realised in Christ, and recognized today and passed on to future generations in the faith of the Church. Theology is to be the proclamation and interpretation of this mystery because it all originates from the original kerygma of the apostles who proclaimed and interpreted the saving events of Christ that they witnessed.

Throughout the first centuries, the theological reflection on faith developed as essentially one "holy knowledge," based on the inspired texts of Scripture and serving the liturgy, proclamation and spirituality. This deep unity can still be seen in the Middle Ages, although the Scholastics have already practiced a parallel commentary on Scripture and theology which we can call systematic. Gradually, however, a separation of strict theology from the liturgy, preaching, ethics and Christian spirituality took place. The division of theology into isolated disciplines finally took place in modern times ${ }^{4}$. Purely speculative theology later attempted an emergence from its isolation by half-hearted means: on the one hand through the so-called dicta probantia (collecting biblical and patristic quotations, often taken out of context, which were often only an illustration and not the basis for dogmatic theses), and on the other hand through the so-called corollaria pietatis (certain remarks of a devotional character on the margins of lectures, e.g. about loving and following Christ). For the purpose of preaching and catechesis, attempts were made to create a separate kerygmatic

3 The problem of Christological concentration in all contemporary theology was the subject of a Christological symposium at the Catholic University of Lublin on 18-19 April 1974. Cf. also A. Nossol, Chrystocentryczny charakter wspótczesnej teologii katolickiej, RTSO 2 (1970), 33-50.

4 Cf. e.g. Y. Congar, Wiara i teologia, in: Tajemnica Boga, Poznań 1961, 142f; M. Herearing, Jedność teologii i jej podział w epoce renesansu i baroku Zarys problemu, in: W. Granat, Dogmatyka katolicka. Tom wstępny, Lublin 1965, 51-65; A. Zuberbier, Materialy do teorii teologii praktycznej, Warsaw 1970, 31. 
theology ${ }^{5}$ instead of strict theology; especially Christology, attempts were made to restore its kerygmatic character. At the same time, other ${ }^{1}$ fields of knowledge and ecclesiastical life were isolated from Christology and the whole doctrine of faith, making it all the easier for them to deviate: ethics became purely legal or philosophical, spirituality - purely moralistic or devotional, biblical, in the field of rationalism and liberal Protestantism - apologetic and historians - contact.

In the last few decades, the need for close communication between all the disciplines of the Church has been rediscovered. The development of biblical studies has allowed apologetic and dogmatic Christology not only to properly justify the foundations of Christianity (to solve the problem of the Christ of faith and the Jesus of history, to reach the pre-paschal Christology and socalled Jesuology, to learn the various stages of shaping the oldest Christian tradition), but also to deepen the interpretation of the main truths of faith, highlight the secrets of revelation often overlooked (such as paschal mystery) and more appropriately show the hierarchy of these secrets in light of Christ's work of salvation. In turn, in close collaboration with dogmatics, biblicalism has become more of a theology than an introduction. It has begun to highlight the main themes of revelation and their mutual relationship; in particular, it seeks to show the very figure of Christ who is the fullness of revelation and the centre of the whole history of salvation.

It was also understood that the life of the Church in its various manifestations was also a criterion of Christian dignity, an expression of tradition, locus theologicus, and at the same time a goal of theological research. Theology as an ecclesiastical science must grow out of today's living faith of the Church and serve it, i.e. it must have by its very nature the character of a kerygma. Moralists, for example, demand that dogmatic ontological Christology is the basis for anthropology and ethics, believing that an end to biblicism alone could threaten some moralizing or philosophical tendencies. They also rightly emphasize that moral theology's analysis of sin, conscience, and freedom of will can be used by dogmatics to deepen the problems of Redemption, the life of grace, and perhaps even to better understand the mystery of Christ's self-awareness. The theology of liturgy in turn draws attention to the paschal mystery of Christ as the centre of the history of salvation, reminds us of the salvific function of the humanity of Christ and the profound sense of the mysteries of the earthly life of Jesus, and finally shows the salvific activity of Christ glorified in heaven and the close

5 Its problems are presented, among others, in: B. Pylak, Teologia kerygmatyczna, in: W. Granat, op. cit., 179-195. 
connection of this activity with the sacramental liturgy and the mission of the Church. Similarly, catechism tries not only to show Christ as an ideal for young people, but also to bring about an encounter with him, the experience of his presence and action in the Church.

On the other hand, the practical disciplines of the Church, through their connection with dogmatics, especially with Christology, can no longer be reduced to moralizing, devotion, rubricism or pastoral techniques, but becomes theology - science with the ability to carry out Christ's plan of salvation. Moral theology, for example, in showing the ideal of the new man, refers to Christology in a reduced way. Liturgy and catechism prepare for a fruitful encounter with Christ in the Word and sacraments. In this way, interdisciplinary cooperation and the Christological correlation of the whole theology are already bearing much fruit, although they are still underdeveloped and many problems still need to be solved 6 .

\section{Council Postulates Integration in Christology}

As far as dogmatic Christology is concerned, the Council's postulates demand that integration be as far-reaching as possible, both historically and systematically.

\section{Integration in the Historical Direction}

Integration in the historical direction must consist in showing the multitude of different varieties of Christology that have evolved over the centuries and, at the same time, the identity of the mystery of Christ that they explain. It is necessary to find a point of view that would make it possible to see the fundamental unity of the content presented by the various Christologies, and at the same time their own specificity, avoiding both the acceptance of one Christology only as a synthesis of all others, and reducing all Christologies to a common denominator, with the blurring of all distinctions.

We also encounter in the Scriptures different approaches to one and the same mystery of Christ, especially the so-called Christology of exaltation - bottom-up,

${ }^{6}$ The problem of specific interdisciplinary cooperation between dogmatic Christology and biblical science, liturgy, moral theology and catechism was presented on the basis of statements in a panel devoted to interdisciplinary cooperation in the field of Christology which took place during the meeting of the dogmatic section of Polish theologians in ATK on 27 September 1974. 
visible in the original apostolic kerygma and in individual synoptics, and the so-called Christology of pre-existence - top-down, in the versions of John's and Peacock ${ }^{7}$. In the patristic period two types of Christology are created in the East (Alexandrian and Antiochian) and one type in Western Christology (African-Roman). Different types of Christology coexisted also in the Middle Ages and modern times, e.g. Thomistic and Scottish, continued today by the so-called unified and divisive Christology (Einigung- und Trennungchristologie). Respecting the multitude of types of Christology, in the Christian tradition we tried to find a common point of view, connecting all these Christologies. This was done, for example, in the formula of reconciliation, just after the Council of Ephesus, and especially according to the Chalcedonian formula. In Scholastica, a common point of view was established based on the ahistorically understood resolutions of the first councils. Nowadays, it is a matter of showing fully the specificity and value of different Christologies, and at the same time their harmonious contribution to the comprehensive illumination of the mystery of Christ, following the example of the richness of colours in the rainbow ${ }^{8}$.

\section{Integration in a Systematic Direction}

Integration in a systematic direction must first consist in integrating traditional Christology: speculative, static, essential, penetrating into the mystery of the Incarnation (and separately into the mystery of Redemption), with biblical Christology: concrete, dynamic, existential, analysing the concrete events known from the Bible, the main mysteries of Christ's life through which the mystery of salvation has been revealed to us and realized.

In the early Church, the teaching of faith was reflected in the second article of the Apostles' Creed, which recalled the main salvific events of Christ's life. Similarly, the entire liturgy and liturgical homilies were focused around these particular events. Later, the Christological article was included in the Trinitarian scheme of the Apostles' Creed and the Church began to develop a speculative "theological" Christology, associated with trinitology. Theologia in patristics had essentially a historical-saving approach, it was closely connected with a specific oikonomy. This happened gradually, especially in the concrete mysteries of Christ's life, no longer as mere events enabling us to know

7 R. Schnackenburg, Christologie des Neuen Testaments, in: MySal vol. 3, part 1 (1970), 227-388; Jesus Christus, in: SM vol. 2 (1968) col. 911-917.927-954.

8 Cf. P. Smulders, Dogmengeschichtliche und lehramtliche Entjaltung der Christologie, in: MySal, op. cit., 389-475; D. Wiederkehr, Entwurfeiner systematischer Christologie, ibid., 477-483. 
the concrete figure of Christ or having a profound sense of salvation, but only from the point of view of their value resulting from the union of persons (that is, from the top-down, deductive path). Only in the liturgy of the ecclesiastical year and the Eucharist the very events of Christ's life through which our salvation was achieved were still remembered and celebrated in an Alexandrian environment (already in Origen's De principiis), the theological Christology as immanent, discussed within the framework of trinitology, was separated from the specific Christology of the Incarnation, the so-called oikonomy. After the Councils in the $5^{\text {th }}$ century defined the essence of personal union, the following topics were also discussed.

In the Middle Ages concrete Christology is basically connected with speculative Christology. In the Elucidarium of Honorius of Autun, in the Sic et non of Abelard, in the Third Book of Lombard's Sentence, the mysteries of Christ's life chronologically were entwined in a lecture on systematic Christology. St. Thomas separated speculative Christology (about the very mystery of the Incarnation) from concrete Christology (about the mysteries of Christ's life and their causal and exemplary influence). At the end of the Middle Ages this division became established and gradually, undoubtedly under the influence of the Aristotelian concept of science as a knowledge of something common and necessary, there was an elimination of concrete Christology from the theological treaties. The lecture of the mysteries of Christ's life is still apparent in the theological treatises of Suarez, but in principle, in common practice, it has moved to devotional-ascetic literature?

It was only under the influence of various trends in modern philosophy, emphasising the importance of history and the meaning of concrete human existence, as well as the development of biblical teachings that show God's revelation in the history of salvation, that the need to deal with the concrete events of Christ's life in Christology was understood anew. Following the example of the first Fathers of the Church, a thorough biblical analysis of concrete events in the life of Jesus began, treating it as a starting point for new interpretations of the very dogma of the Incarnation ${ }^{10}$.

Integration in Christology must then consist in integrating Christology in the narrowest sense of the science of uniting two natures in one person with soteriology (the science of Redemption), or ontological Christology (the science of Christ

9 Cf. A. Grillmeier, Christologie, in: Lexikon für Theologie und Kirche, vol. 2 (1958) col. 1157ff; in: SM vol. 1 (1967) col. 871-785; Geschichtliche Überblick über die Mysterium Jesu im allgemeinen, in: MySal vol. 3, part 2 (1969), 3-22.

10 An example of such a concrete Christology is e.g. the work of C. Duquoc, Christologies, 2 vol., Paris 1968-1972. 
in itself) with functional Christology (the science of the meaning of Christ for us). So it is about combining the Christology of the Incarnation with the Christology of the Cross and the Passover, and referring to the patristic tradition the theological Christology (theology) with economic Christology (oikonomy).

Although the division of Christology into theology and oikonomy took place already in the patristic period, the Fathers strongly emphasized the relationship between the Person of the Son of God and the economy of salvation. They even argued that if Christ had not been God, He would not have completed our Redemption. By closely associating the Incarnation with Redemption, they demonstrated that the very Incarnation of the Word was a renewal of mankind. Latin Christology in particular had a soteriological character. Soteriology did not separate from Christology until the $12^{\text {th }}$ century, largely under the influence of the Anselmian theory of alternative redress. The first case of the separation of soteriology from Christology is encountered in the Sentences of Arras (Atrebathenian). Reformists in the $16^{\text {th }}$ century against Scholastica and referring to St. Paul and St. Augustine emphasize the soteriological character of Christology. They oppose the theology of the Incarnation, which explores the ontological structure of the God-Man, the theology of the cross which penetrates into the meaning of God's salvific action in Christ's life, especially in his death and resurrection ${ }^{11}$.

Under the influence of Evangelical Christology, as well as developing biblical theology and an anthropocentrically oriented contemporary philosophy (existential phenomenology), in recent years attention was paid to the soteriological character of the whole Christology and the development of socalled functional Christology. The object of research is not so much Christ in Himself as Christ for us: in His function of our mediator, in relation to our salvation. By emphasizing Christ's mission and the salvific meaning of all his life, Christ's central place in the whole history of salvation and even, under the influence of Teilhard, in the whole process of evolution of the cosmos is also revealed. In principle, it is understood that there is a need not to limit oneself to functional Christology itself, but to combine it with ontological Christology. However, such a holistic Christology is only in statu fieri. At the same time, the harmony between biblical and systematic Christology looks different. Sometimes they are presented in parallel, sometimes one of them becomes the main basis or starting point of the other ${ }^{12}$.

11 Cf. A. Grillmeier, Christologie, art. cit.; J. Ratzinger, Wprowadzenie w chrześcijaństwo, Kraków 1970, 180-193.

12 Cf. R. Lachenschmid, Christologie und Soteriologie, in: Bilanz der Theologie im 20. Jahrhundert, vol. 3, Freiburg 1970, 82-120. 
Finally, integration must consist in a Christocentric orientation of all dogmatics, i.e. the so-called Christological concentration, i.e. the presentation of the mystery of Christ as the centre of the whole history of salvation. It is a matter of showing the deep and manifold connections between Christology: on the one hand, Trinitology, the science of the inner life of the Father giving Himself to us through his Son in the Holy Spirit, and on the other hand, anthropology, ecclesiology, theology of history, eschatology, theology of the whole history of the salvation of mankind, the gradual manifestation and realization of the biosphere of salvific plans for the whole world, not only in human, but also in cosmic dimensions ${ }^{13}$.

It is worth mentioning that in the history of theology we encounter a double view of the subject of this discipline. According to St. Thomas, Henry of Ghent and Johannes Duns Scotus, this object (understood as a subiectum and not obiectum) is God as God (sub ratione Deitatis). According to St. Augustine, Kasjodor, Robert of Melun, Roland of Cremona, R. Kilwardby, R. Grosseteste, G. Biel and P. d'Ailly, it is Christus totus aut integer; so we have a certain concept of Christocentrism here. Nowadays, Christological concentration in theology is trying to be undertaken in a double way. Traditionally, the mystery of Christ is placed in the middle of a dogmatic lecture, treating the mysteries of faith discussed earlier and later - as preparation for it and as its consequence. Sometimes it is placed at the beginning of dogmatics, as a starting point for the whole history of salvation. Each of these views has its advantages and disadvantages and some excellent solution has not been found yet.

\section{Contemporary Attempts at Integration in Christology}

\section{Rahnerian Attempt of Integration in Christology}

$\mathrm{K}$. Rahner gives outlines of integration in his articles, propagating the concept of so-called transcendental Christology, closely connected with anthropology,

13 The problem of such integration was presented more extensively by A. Nossol in a paper entitled A new attempt to formally grasp the mystery of Christ in dogmatics, delivered at a Christological symposium at the Catholic University of Lublin on 18 April 1974. The very need for such integration was justified by the same author in several of his articles. Cf. Teocentryzm czy chrystocentryzm w wykładach teologii dogmatycznej, CoTh 41(1971)2, 15-28; Prymat christologii w dogmatyce, AK 79 (1972), 90-400; Potrzeba chrystologicznej interpretacji w teologii dogmatycznej dzisiaj, RTSO 4 (1974). Cf. also K. Reinhardt, Neue Wege in der Christologie der Gegenwart, "Communio" 6 (1977), 5-20. 
or even identified with it ${ }^{14}$. It shows Christ as the mediator and peak of transcendence of all creation towards God and at the same time the self-giving of God to all creation. He interprets the Incarnation of Christ itself as the absolute highest - though unnecessary and undue - and the only fulfilment of the human transcendence open to the Absolute Being, and at the same time as the most radical personal self-responsiveness of the God of Humanity.

Rahner and W. Thusing published a comprehensive, almost textbook study of Christology in the Quaestiones disputatae series ${ }^{15}$. This study is divided into two parts. The first, the work of Rahner himself, gives an outline of a dogmatic lecture on the doctrine of Christ, contained in 35 theses and extensive theorems. These theses are grouped in the following 5 chapters: I. To the phenomenology of our attitude towards Jesus Christ; II. Transcendental Christianity; III. To the theologically understood history of the life and death of Jesus; IV. Theology of Jesus' death and resurrection; V. Contents, durability, boundaries of classical Christology and soteriology and new orthodox possibilities of soteriological Christology. The second part of the work, elaborated by W. Thusing, is a biblical development and deepening of the dogmatic lecture and a critical examination of Rahner's theses in light of the latest exegesis results. Thusing also discussed the very problem of cooperation between exegetes and dogmatics in theological research, the critical function of the New Testament in relation to classical Christology, and the importance of Christology for all theology, and ecclesiology in particular ${ }^{16}$.

Depending on Rahner's concept of Christology, there remains an extensive textbook entitled Das Christusereignis, taking into account almost all the achievements of modern Christology, but not forming a compact whole ${ }^{17}$. It sees the mystery of Christ as the greatest work of the Father, Son and the Holy Spirit, known increasingly more precisely in the history of revelation and in the first centuries of Christianity. This work is the point of God's greatest closeness to the world and, thanks to the saving mission of Christ, carried out mainly in the paschal mystery, it is at the centre of the whole history of salvation. The authors present in the following chapter: introductory remarks on the topic; Christology, the saving action of the Father in Christ; the foundations of Christology

14 Cf. Schriften vol. 1, 160-222; vol. 4, 137-155; vol. 5, 183-221, vol. 8, 213-235; vol. 9, 194-388; Jesus Christus. III. Dogmatische Vermittlung, in: SM vol. 2 (1968) col. 927-957.

15 K. Rahner, W. Tüsing, Christologie-systematisch und exegetisch. Arbeitsgrundlagen für eine interdisziplinäre Vorlesung (Quaestiones Disputatae 55), Freiburg 1972.

16 Cf. review by E. Ozorowski, STV 12(1974)2, $262 f f$.

${ }^{17} \quad{ }^{17}$ MySal vol. 3, part 1 (1970) and part 2 (1969). 
in the Old Testament; the Christology of the New Testament; the development of Christology in antiquity; the outline of systematic Christology (its general principles and the understanding of the whole reality of Christ within the framework of God's relationship to the world and the world to God); the saving functions of Christ as Revelator, Lord and Priest; the mysteries of Jesus' life; the paschal mystery; the effectiveness of God's saving action in Christ; the place and participation of Mary in Christ's mystery; the mystery of Christ as the work of the Holy Spirit; and finally Christ in the reach of the experience of the world.

\section{Integral Christology by W. Pannenberg, Ch. Duquoc, W.Kasper and E. Schillebeeckx}

Many theologians have recently made radical attempts to rework integral Christology, based primarily on biblical theology.

W. Pannenberg, an Evangelical theologian, emphasizes the unity of soteriology with Christology and the connection between functional and biblical Christology, and ontological and traditional Christology. He divided his work into three parts: I. Awareness of the divinity of Jesus; II. Jesus the Man before Jesus the God; III. The divinity of Christ and Jesus the $\mathrm{Man}^{18}$. In the beginning, he discusses the tasks and methods of Christology and its strict unity with soteriology. In the first part, he speaks of Jesus' resurrection as 'the basis of his unity with God, and analyses comprehensively the relationship between "the deity of Jesus and the deity of the Father. In the second part he examines successively the meaning of Christ's true humanity, the meaning of his messianic function and the salvific meaning of Christ's substitute death on the cross. In the third part, it is first characterised by the impasse of traditional doctrines of the two natures in Christ. He then tries to outline his own approach to the mystery of Jesus' personal unity with God, combining the dialectical patristic theory of enhypostasis with modern theories of the peak of fulfilment in the Jesus' sonship of the human personality. Finally, he mentions Christ's royal power, pointing out that the recapitulation of mankind took place through Christ.

Ch. Duquoc makes an attempt in these two volumes to rework Christology based on a thorough analysis of biblical statements about the specific events and functions of Jesus ${ }^{19}$. In the first volume, the author first examines the mysteries of the earthly life of Jesus and the messianic titles and divine-human status

18 W. Pannenberg, Grundzüge der Christologie, Gütersloh 1964.

19 Ch. Duquoc, Christologie. Essais dogmatique, vol. 1, L’homme Jésus, Paris 1968; vol. 2, Le Messie, Paris 1972. 
shown by the Bible and then presents an interpretation of the mystery of Christ in different periods and in different currents of the Church's traditions. In the second volume, he discusses in detail "Christ's messianic mission: the events of Christ's Passion and worship, the various interpretations of Redemption, the importance of messianism in history, the problem of paralysis, and the meaning or value of Christ's revelation.

W. Kasper tries to summarise the synthesis of Christology as the doctrine of the person and work of Christ in the claim that Jesus is Christ ${ }^{20}$. At the beginning of his work, he reflects on the general issues of contemporary Christology and the figure of Jesus Himself, his historicism and religious value for today's man. He emphasises that the first criterion of Christology is the earthly Jesus and the resurrected Christ. The starting point must also be the faith of the ecclesial community in the fact that Jesus is Christ. The main content of Christology is the cross and the resurrection of Jesus, and its main problem is to explain the relationship between the Christology of "ascending" (worshipping Jesus) to the Christology of "descending" (Incarnation of the Word). Next, the author presents in two parts of the work the history and destiny of Jesus and the mystery of his figure, revealed in the titles awarded to Him. In the first part, he shows the way from the earthly Jesus (thoroughly analysing his appearance on earth, proclaiming the kingdom of God, doing miracles, claims expressed in the messianic titles, and finally death) to the risen Christ (explaining both the foundations and the content of faith in the resurrection of Jesus). In the second part, he tries to delve into the mystery of Jesus Christ by interpreting His biblical titles: the Son of God, the Son of Man, Mediator between God and man. In both parts he tries to discover the close relationship between the figure of Jesus and His life and the work of salvation of mankind. This relationship is particularly evident in Jesus' death and resurrection, and in the Messianic titles awarded to him.

E. Schillebeeckx calls his work about Jesus a reflection on someone who lives ${ }^{21}$. At the outset, he suggests the problems of criteria, methods and hermeneutics of Christology. He first states that the norm and the criterion for any interpretation of Jesus of Nazareth must be Himself. He then presents the criteria for knowing Jesus as a historical figure. Finally, he explains the division of his further Christological analyses into three parts: I. Gospel of Jesus Christ; II. Christian interpretation of the Crucified Risen One; III. For whom do you

20 W. Kasper, Jesus der Christus, Mainz 1975.

${ }^{21} \quad{ }^{21}$ E. Schillebeeckx, Jesus-het verhaal van een levende, Rrugge-Bloemendaal 1974. 
have me? In the first part, he speaks first of the gospel of the kingdom of God proclaimed by Jesus both in oral teaching (beginning of prophetic activity baptism in the Jordan, proclamation of the kingdom of God, parables, blessings) and in the whole practice of life (miracles, community of table and life with disciples, attitude towards the Father in heaven). He then mentions the kingdom of God fulfilled in the rejection of Jesus by the Jews and His death (the meaning of Jesus' death shown by Himself). Finally, he deals with the testimony of the first Christians on the death of Jesus, the empty tomb, Christophany and the paschal experience (the conviction of Christians that the Crucified is alive and that God's kingdom is present in him).

In the second part, devoted to the Christian interpretation of the Crucified Risen One, the author analyses the evangelical, general interpretation of the Risen Jesus (various pre-Canonical models of the faith in Christ), the New Testament interpretation of the resurrection event itself (biblical expressions of faith in the resurrection), the passage from theology of Jesus to Christology, and finally the post-New Testament Christological reflection in the ancient Church (Christological dogma). In the last part he tries to answer, in the name of contemporary man the question once posed to the disciples by Jesus: For whom do you have me? He presents the contemporary crisis of Christology as a legacy of the Enlightenment, the non-theoretical "universal horizon of understanding" (man crushed by suffering constantly asks what their meaning is and how to be liberated from it) and the figure of Jesus as the "parabola" of God and the "paradigm" of humanity (the image showing God and His salvific activity in history and the model or prototype of humanity living in the kingdom of God).

\section{Integral Christology in the View of L. Bouyera, B. de Margerie and C. Chopin}

Less radical attempts at integration in Christology can be found in works referring to traditional Christology.

L. Bouyer develops Christology as one of the departments of great theological synthesis. He divides his reflections into two parts: I. Creation and salvation (the following volumes of this part are devoted to the economy of salvation: the Mother of God, as a prototype of the supernatural state of humanity, to the Church and - the volume being prepared - to the glory of God revealed by the universe); II. Learning about God (here he intends to include theology as a teaching about God in the Trinity in the following volumes: the Eternal Son, the Spirit of Consolation and the Invisible Father). The volume on the Eternal 
Son is dedicated to the theology of God's Word and Christology, treating it as a transition from the economy of salvation to theology ${ }^{22}$. The whole lecture about Christ is presented in three parts. In the first one, he speaks of "preparation" or gradual manifestation of the Word of God in the Old Testament (Word of God, Wisdom, Kingdom of God, Messiah, Servant of the Lord, Son of Man, waiting for the consolation of Israel). In the second, called the "Resurrection," he presents the Christology of the New Testament (the gospel of Christ - the gospel preached by Christ, the course of the gospel from the teaching of the kingdom of God to the Passion, the resurrection and kerygma, the Christology of the early Church, St. Paul, the individual evangelists and the letter to the Hebrews). The third outlines the history of efforts to understand faith in Christ (the problem the faith of the Apostles to the Creed of Nice and Constantinople, between Nestorianism and monophysitism, scholastic Christology, modern Christology - between metaphysics and psychology). At the end of this part, the author expresses his own concept of Christology as a transition from the Word of God revealed to men to the Eternal Son residing with the Father, that is, from the economy of salvation to theology.

B. de Margerie's lecture on Christ and His mission in the world revolves around the following three problems: why to discuss Jesus, how to talk about Him today and what is His mission in the world ${ }^{23}$. In the first part of his work, the author emphasises the absolute and universal primacy of Christ the Redeemer in the world and shows the relationship of non-baptised people and non-Christian religions with Christ's work of Redemption, stating that the raison d'être of Christ in the Church and in the world is God's salvific dialogue with people, realized throughout history. In the second part he analyses various contemporary approaches to Christology (Teilhard, Bultmann, Bonhoeffer from an earlier and later period, creators of the theology of secularisation and sanctification of the world), trying at the end to show the synthesis of profanum and sacrum in the consecrated Heart of Jesus. In the last part, he first considers the contribution of the former councils, Luther and the Council of Trent to the teaching of Christ's mission in the world (especially the emphasis on the teaching of the new Adam). He then presents the doctrine of Vaticanum II about Christ as a prophet, priest and king. Finally, by analysing individual aspects of the mystery of Redemption, he presents the Eucharist and the Heart of Jesus as a synthesis and the final accomplishment of the universe, history and revelation.

22 L. Bouyer, Le Fils éternel. Théologie de la parole de Dieu e christologie, Paris 1974.

23 B. de Margerie, Le Christ pour le monde. Le Coeur de l'Agneau, Paris 1971. 
A slightly older attempt at the partial integration of Christology is the textbook developed by C. Chopin. He presents Christology and soteriology first in a biblical then a systematic way - as two parallel parts of one whole, i.e. the mystery of the Incarnate Word and His salvific mission. He first discusses Christology and biblical soteriology, then the theology of the Incarnation and the theology of the mediation of the Incarnate Word presenting the mystery of Redemption as part of a lecture on the priestly function of Christ.

\section{Attempts at Christological Concentration in all Theology}

Attempts at a more compact integration in Christology, and even the Christological concentration of all theology, are given in the latest ${ }^{24}$ textbooks of dogmatics, developed by A. Zuberbier, M. Schmaus and W. Granat. They present the mysteries of Christ as the centre of all dogmatics and incorporate into a unified lecture on Christology not only the doctrine of Redemption as Christ's saving action, but also the doctrine of the Trinity as the main content of Christ's teaching.

A. Zuberbier's textbook is very concise and intended for a wide range of readers ${ }^{25}$. The author introduces us to the historical figure of Jesus of Nazareth, and then presents what Jesus teaches us about Himself, our Father in heaven, about the world as a work of God, about God giving Himself to people despite their infidelity, about the coming of the kingdom of God in His person and activity. He discusses the central event of Jesus' salvific activity - the paschal mystery and the fruits of this mystery: the mission of the Holy Spirit, the Church of Christ (its nature, sacramental life, the mission to preach the gospel, testimony of Christ and attitude to the world) and the final conclusion of the work of Redemption on the day of the Second Coming.

A new textbook by M. Schmausfirst presents the teachings of the Old Testament about God, creation, sin and angels ${ }^{26}$. He then discusses in turn the deeds of Jesus Christ (especially the salvific death and resurrection), His words (revelation of the Trinity) and the very essence of Christ in biblical and systematic terms ${ }^{27}$.

24 C. Chopin, Le Verbe Incarné et Rédempteur, Toornai 1963; Polish translation: Tajemnica Chrystusa, Poznań 1969, 167-310.

25 A. Zuberbier, Wierzę. Dogmatyka w zarysie, Katowice 1969.

26 M. Schmaus, Der Glaube der Kirche. Handbuch katholischer Dogmatik, vol. 1, München 1969, 251-430.

27 Ibid., 431-689. 
The recently published handbook by W. Granat speaks about the way of man to God and God towards man before Christ, and then about the meeting of people with God through Christ and in Christ. This lecture on this meeting includes topics such as: Christ's historicity, his humanity and divinity, saving mysteries, teaching about God, the nature of man and his friendship with God, man's response through faith, hope and love, and the role of Mary and others in Christ's salvific missions ${ }^{28}$.

H. Kung does not write a textbook of dogmatics but in his controversial work Christ sein tries to present a vision of Christianity that is most appropriate in his opinion to the contemporary seeker ${ }^{29}$. All his arguments are focused mainly on the Jesus Christ Himself. It first shows the spiritual horizon of our time as a liberation of Christianity from the influence of modern religious humanism and non-Christian religions. He then explains what the specific character of Christianity is. He confesses that Christianity is not limited to ideology, but to the person of Jesus Christ, and that Jesus, in the light of history and faith, is a real person. In the main part of his work he analyses thoroughly the entire program of Christianity shown by Jesus Himself. He first illuminates the social context of Jesus' activity and states that it directly provocatively destroys all social life patterns. It expresses the view that Jesus in all his activities is concerned both with God's cause (the centre of his existence and the proclamation confirmed by miracles in the coming kingdom of God and the highest norm is the fulfilment of God's will) and with man's cause (Jesus' theocentrism includes anthropocentrism, concern for the humanisation of man; the norm of his actions towards people is love, expressed in forgiveness, service and self-denial). It then signals Jesus' conflict with the Jewish hierarchy, which ended with his death and the new life of the Risen One. He explains that the resurrection was a transhistorical event, not subject to human control and not requiring evidence, that it was only the post-paschal community and the evangelists themselves who began to multiply various kinds of evidence (in the form of a relationship about an empty tomb and Christophany) and that in the resurrection it is ultimately about our conformity to Christ through the practice of faith in life. He goes on to analyse the problem of interpreting the gospel, stating that it contains many myths that require reinterpretation, as well as a number of different interpretations, and show Jesus exclusively in His functions toward us. Hence calling the Christ God according to him would mean that Jesus of Nazareth is the revelation 
of the true God for faith. Finally, he writes about the emergence of the Church as a community of faith in Christ, outlining here his ecclesiology as depicted in Die Kirche. After a detailed outline of the program of Christianity, the author in the last part speaks about the very practice of being a Christian. He considers whether the decision for believing in Christ is at the same time a decision for the Church and what are the criteria for being human and being a Christian. In the end, he concludes that being a Christian means being radically human because following Christ comes down to loving one's neighbour.

\section{Conclusion}

1. The need for multiple integration in Christology as well as the Christological correlation of all theology must not raise any doubts nowadays. As we have seen, this is supported by the clear indications of the last Council as well as by the multiple tendencies that can be seen in the post-conciliar renewal of theology. The Christological correlation of theology profoundly corresponds not only to its unity, but also to its return to biblical sources, to apostolic tradition and its kerygmatic character, the proclamation of the mystery of salvation and the call to faith. Similarly, the systematic integration of Christology itself, the greater link between biblical and speculative Christology and the mystery of the Incarnation and the mystery of Redemption allow it be possible to make from the mystery of Christ the central theme of the entire lecture on dogmatic theology and, more importantly, to show Christ and his salvific works as eternally living and highest value in which we are involved and to which we are to make a full consecration. The integration of the different directions of Christology better reflects the unfathomable richness of the revealed truth about Christ and the history of constant efforts of Christian thought to penetrate this truth most deeply. It also takes into account the specific circumstances that have led to the gradual clarification of the various aspects of the mystery of Christ in dogmatic definitions. Finally, it emphasises the fact that one and the same Christian faith has been expressed over the centuries in different traditions in the East and West, and that there has almost always been a variety of theological approaches to one and the same Christological dogma. Therefore, such an integration of Christology is of great importance for the preparation of ecumenical dialogue and the proper exposition of the problems of theological pluralism and reinterpretation of dogmas.

2. However, it is difficult to find any ideal way to achieve this correlation and integration. Attempts made so far show many different possibilities, each of which 
has its advantages and disadvantages. As for the Christological correlation of the whole theology, especially the dogmatic, one can take Christology - the science, the work and Christ Himself - as the starting point for the lecture of all other theological treatises because the whole salvific economy of God was revealed to us fully only in the mystery of Christ. It is also possible, following the traditional dogmatic system, to consider Christology as a central theological treatise and to show that the whole revelation of God and the history of salvation were directed towards Christ, that in him they found their full realisation, and that the further history of salvation in the Church in the world until the second coming of the Lord is the continuation of Christ's salvific work and derives its meaning and effectiveness from the mystery of the Incarnation and Redemption. The systematic integration of Christology itself can also take on different forms. It is possible to move from Christ's work, His words and deeds to His person, or from Christ's person to His work. In other words, it is possible to begin by showing what Christ has done, and then analyse who he was, or vice versa. The first way is probably more in line with the biblical phenomenological character of the latest approaches to Christology. The second follows the line of traditional concepts.

Integration in the historical direction can also be carried out in different ways. The prospective method recommended by the Council can be adopted, i.e. to show the gradual development of the revelation of the mystery of Christ in St. and N. The Testament and the development of an awareness of faith in this mystery in the history of the Church up to the present day, the formation of different traditions and many theological approaches, while preserving the essential identity of faith, is precise where necessary in symbols of faith and dogmatic definitions. It is also possible to use a more traditional retrospective method, i.e. to present today's awareness of the Church's faith in the mystery of Christ with various theological controversies and emerging problems, and, going back through centuries of Church tradition and the development of theological thought, to show the whole historical-biblical background of Christian Christology. This will prove its identity and at the same time its constant development and richness of views. Thus, theologians, lecturers and textbook authors have different possibilities to implement the postulates of correlation and integration. The lack of one ready-made model in this field as a result of the ongoing process of post-conciliar renewal of the entire theology sometimes gives rise to some anxiety. However, it is a creative anxiety, protecting against routine and ossification. This situation makes it necessary to rethink and adapt the lectures on the central mystery of Christianity to the current conditions and needs of the listeners in order to revive their faith and commitment to the salvific work of Christ. 